\section{Is Social Media Having any Impact on Teaching and Learning Practices?}

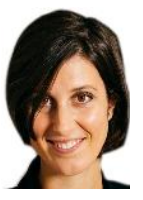

Sharon Wilson

University of Central Lancashire, United Kingdom.
Global Journal of Social Sciences Studies

Vol. 7, No. 1, 12-23, 2021

e-ISSN: 2518-061

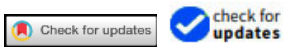

The study has focused on determining the impact of social media on the teaching and learning practices. The design of this study is quantitative as the data has been gathered from the students and teachers through survey questionnaire. The number of respondents were 280. The analysis was carried out on SmartPLS in which the Structural Equation Modelling (PLS-SEM) was used. Therefore, the data was analysed using measurement model and path assessment with reflective constructs. The results revealed that there is overall significant effect of collaboration and interaction, creativity and knowledge sharing on learning practices. On the other hand, creativity, knowledge sharing and use of SNS had significant influence over teaching practices. The study is limited to the educational practices as it determines the effect of SNS on the teaching and learning practices.

Keywords: Collaboration, Interaction, Knowledge sharing, Use of SNS, creativity, Teaching practices, Learning practices.

DOI: $10.20448 / 807.7 .1 .12 .23$

Citation | Sharon Wilson (2021). Is Social Media Having any Impact on Teaching and Learning Practices? Global Journal of Social Sciences Studies, 7(1): 12-23.

Copyright: This work is licensed under a Creative Commons Attribution 3.0 License

Funding: This study received no specific financial support.

Competing Interests: The author declares that there are no conflicts of interests regarding the publication of this paper.

History: 7 January 2021/ Revised: 15 March 2021/ Accepted: 19 April 2021/ Published: 25 May 2021

Publisher: Online Science Publishing 


\section{Highlights of this paper}

- This study investigates the impact of social media on the teaching and learning practices.

- The results revealed that there is overall significant effect of collaboration and interaction, creativity and knowledge sharing on learning practices.

\section{INTRODUCTION}

The present research is aimed towards assessing the importance of social media for practices of teaching and learning. In the current learning environment, there has been a significant emergence of the social network sites which has revolutionised the communication tools for facilitating learning and teaching activities (Devi, Gouthami, \& Lakshmi, 2019). Moreover, there has also been tremendous evolution in the utilisation of social media websites among people as it provides accessibility and ease of communication. Furthermore, the application of Social Networking Sites (SNSs) in the learning and teaching offers a positive influence over the adoption of SNSs and mainly opens doors for learning and teaching (Abbas, Aman, Nurunnabi, \& Bano, 2019; Javaeed, Kibria, Khan, \& Ghauri, 2020). However, the recent attention of the students towards social networks brings safety and privacy concern within the educational environment. Considering this discussion, the main purpose of this research is to assess the impact of social media on learning and teaching practices.

Concerning the aim of this study, it can be identified that is has become essential for the educational institutes to analyse that importance of social media (Chu \& Kim, 2011). Therefore, the objective of this study is to study and evaluate the concept and significance of social media. Instead, the methods of teaching and learning have been evolving all over the world in which most of the institutes are concerned over the most effective teaching and learning methods. In this manner, the second objective of this study is to identify the importance of contemporary teaching and learning practices. This will help the educational institutes to determine the importance of these modern teachings and learning processes to implement them. Lastly, the third objective is to assess the impact of social media on learning and teaching practices. In this manner, the study is focused on answering the question that what is the importance of social media on practices of teaching and learning with the help of analysis carried out in this study.

\section{LITERATURE REVIEW}

Over the years, the use of social networking sites (SNS) has been increased among the young generation which has grabbed the attention of educational institutions in terms of utilising this platform in teaching and learning of students. It has been argued in the study of Devi et al. (2019) that the tools of social media have created the platforms for the betterment of the educational process. Moreover, to the evaluation process, the use of social media enriches the teaching and learning process with audio, video and text materials (Urista, Dong, \& Day, 2009). There is a great interest of college students in social media. This is due to the reason that they spend most of the time on these SNS and may like to learn through them. In this manner, the social media was determined as LinkedIn, MySpace, Twitter, Blogs, YouTube and Facebook (Wang, Chen, \& Liang, 2011).

The social networking sites which include most public internet-based services allow the users to create a personal profile while enabling them to react and read on the posting sites (Devi et al., 2019). In this manner, the individual users must restrict the information while posting it on social networking sites (SNS) while being aware that the information can be shared among people publicly. It includes favourite movies, books, relationship status and birthdays. In this regard, the students who are unwilling to participate in the class discussion while hesitating to speak are provided with the opportunity to share their views over the internet. Therefore, the learning of students has been enhanced with the emerging of new web tools. Due to the use of Facebook among upper-class 
students to participate in the college life and socially connect with their peers, the association among well-beings and Facebook is appeared to be positive over the college years (Kalpidou, Costin, \& Morris, 2011).

It has also been believed by the educational institutions that the value is offered in teaching by social media sites. In addition to this, it has also been believed that the wikis, podcast and videos are considered as the valuable tools for teaching while most of the students and institutes believe that the use of SNS is effective in terms of collaborative learning (Moran, Seaman, \& Tinti-Kane, 2011). The transformation of social and personal changes has been carried out by the social media throughout the communication world about the young generation which uses social media as the communication tool. In this manner, more effective cooperation can be achieved by the students in their studies if they can make friends outside traditional channels.

The SNS have now become part of the teaching community and in this manner, most of the teachers have gain knowledge by interacting over SNS. However, some of the teachers still reject to use this technology as they resist the change and prefer the conventional methods of teaching students. These types of teacher believe that social networking sites are not for providing education to students (Roblyer, McDaniel, Webb, Herman, \& Witty, 2010). The notion of social media cooperative learning with the help of SNS like applications for the conference, Facebook, YouTube, Email or other types of websites let the students in to discuss and communicate well with the teachers and other students (Hamid, Waycott, Chang, \& Kurnia, 2011). Therefore, the first hypothesis of this study has been developed which is provided below:

\section{$H_{1}$ : Use of social networking sites have significant influence over teaching practices.}

The contemporary practices of learning have become more effective in terms of the understanding and memorisation of students (Khan, Ahmed, \& Amin, 2017). In this manner, the students have started focusing on learning through social media. This is due to the reason that students find it easy to learn through social networking sites as they spend most of the time while socialising (Hamat, Embi, \& Hassan, 2012). Therefore, the second hypothesis of the study has been provided below:

\section{$H_{2:}$ Use of social networking sites have significant influence over learning practices.}

The creativity of students in academics has been associated with the creative undertakings in the educational structure which depends typically on the concerted activities of a teacher (McWilliam \& Dawson, 2007). In this manner, it is suggested for the teachers to adopt different creative practices to teach the student creatively like collaborative play and fun which help the students to thinks creatively. In this manner, the third hypothesis of the study is provided below:

\section{$H_{s:}$ Creativity through social media have significant influence over teaching practices.}

Students are benefited by the use of SNS in classrooms. This is due to the reason that the critical thinking ability of the student is developed by social networking along with the augmentation and confidence (Khan et al., 2017). It also helps them to increase their social interaction with other students or classmates which can enhance their skills while having a discussion. In this manner, students can enhance their learning abilities. Therefore, the fourth hypothesis of the study is provided below:

\section{$H_{4}$ : Creativity through social media have significant influence over learning practices.}

The use of SNS helps teachers in terms of dealing with everyday issues while encouraging collaboration. It is because that the use of SNS allows the teachers to share relevant information with the students (Khan et al., 2017). On the other hand, despite sharing the relevant content with the students, it is also considered as best practice in an environment while developing solid learning policy. In addition to this, it also creates countless space for collaborating, partaking experiences and updating and researching the knowledge of someone. The fifth hypothesis of the study is provided below: 


\section{$H_{5:}$ Knowledge sharing through social media have significant influence over teaching practices.}

On the other hand, there is also a great influence of knowledge sharing on the learning capabilities of students. This is due to the reason that sharing knowledge over the internet helps the student to better learn the different aspects with the discussion (Johnson, 2016). In this manner, it is essential to recognise the impact of knowledge sharing on social media over the learning practices of students. Therefore, the sixth hypothesis of the study is presented below:

$H_{6:}$ Knoweledge sharing through social media have significant influence over learning practices.

Rather than being an online community, SNS interact and reflect with the actual community. High school classmates become friends with college students and people living at the campus can interact with other students as well. There are several websites which include Live Journal, Type pad, Flickr, YouTube, Twitter, Facebook and LinkedIn which are being used for the educational and interactive activities (Khan et al., 2017). Therefore, the seventh hypothesis of the study is presented below:

\section{$H_{7:}$ Collaboration and Interaction on SNS have significant influence over teaching practices.}

On the other hand, the collaboration and interaction also increase the discussion students in the classroom which enhances the ability of all the students to think broadly. Therefore, the students must interact with other students over social networking sites. On the other hand, the students are also able to learn in a better manner with collaboration. Therefore, the eighth hypothesis of the study is provided below:

\section{$H_{s:}$ Collaboration and Interaction on SNS have significant influence over learning practices.}

\subsection{Theoretical Framework}

Pertaining to the increased preference of students to learn and teachers to teach through social media, it is necessary to identify this behaviour and its causes. In this manner, the Uses and Gratification theory is applicable in this context which helps to determine the behaviour of teachers and students. According to Eginli and Tas (2018) that Uses and Gratification theory helps to comprehend how and why people pursue specific media actively to satisfy specific needs. In addition to this, the UGT is regarded as the viewer's centred approach for considerate mass communication. Despite the additional media theories which focus on what does the media ensure to people, the Uses and Gratification theory emphases on what the people are doing with the media. This theory suggests that media is the product which is highly available while the audiences on social media are the consumers of the same product. Therefore, the impact of social media on practices of teaching and learning can be determined along with the increased preference of student to learn through social networking sites.

\subsection{Conceptual Model}

This study has focused on identifying the impact of social media on practices of teaching and learning. Therefore, the independent variable of the study is social media which has been measured through four independent variables. These variables include the use of social networking sites, creativity, knowledge sharing and collaboration and interaction. On the other hand, there were two dependent variables which include the teaching practices and learning practices. In this manner, the impact of social media has been measuring in practices of teaching and learning. The conceptual framework of the study is provided below: 


\section{Independent Variables}

\section{Dependent Variables}

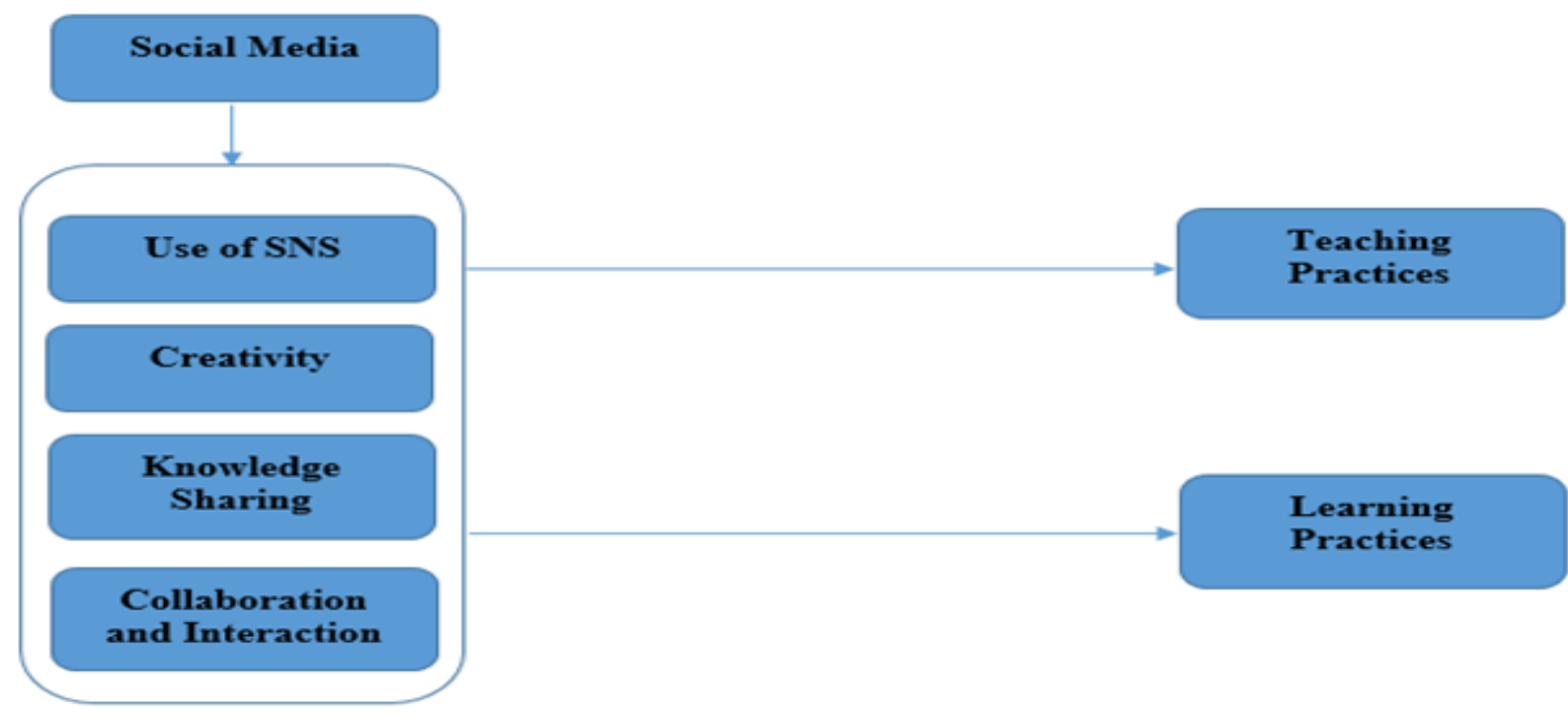

Figure-1. Conceptual model of the study.

\section{METHODOLOGY}

The study adopted quantitative research design where the data has been collected from students and teachers of different institutes. The total sample size of the study will be 280 respondents. A survey questionnaire was developed constructed on a 5-point Likert scale for measuring responses to each item ranging from Strongly Agree to Strongly Disagree). For the analysis, Smart PLS has been used to assess the importance of social media on teaching and learning practices. Moreover, SEM (structural equation modelling), CFA (confirmatory factor analysis) and path analysis have been used.

\section{RESULTS}

\subsection{Measurement Model-Partial Least Square Algorithm (PLS)}

The CFA analysis has been carried out by the researcher in this section of the study which is used for the determination of measurement model. In this regard, the reliability of the latent construct has been tested which has the threshold of 0.6 in terms of the composite reliability and Cronbach's Alpha (Avkiran \& Ringle, 2018). From the Table 1 it can be determined that the lowest value of Cronbach's alpha is computed to be 0.816 while the lowest value for composite reliability is computed to be 0.892 . In this manner, it shows that both the composite reliability and Cronbach's alpha fulfil the criteria of reliability. Additionally, the other significant aspect of the CFA analysis is the assessment of outer loadings that has also been conducted by the researcher. It has been argued in the study of Vinzi, Chin, Henseler, and Wang (2010) that the values for outer loadings must be greater than 0.6. Therefore, it can be determined on the basis of Table 1 that the minimum value for outer loadings is computed to be 0.611 .

Moreover, the significance of the outer loadings was also determined using the bootstrapping model which was also found to be significant. In contrast to this, the association and relatedness of the latent constructs are tested using the convergent validity. In this regard, the study of Jefferies and Cubric (2015) stated that the threshold for AVE is 0.5. Therefore, it can be determined with the help of Table 1 that all the variables possess the convergent validity as the minimum value for AVE is 0.657. Moreover, the aspects have also been determined from Figure 2 as the model comprises the reflective constructs in which the latent variables have caused the indicators (Hair Jr, Hult, Ringle, \& Sarstedt, 2016). 
Table-1. Reliability and convergent validity.

\begin{tabular}{|c|c|c|c|c|c|}
\hline Variables & Indicators & $\begin{array}{c}\text { Outer } \\
\text { Loadings }\end{array}$ & $\begin{array}{c}\text { Cronbach's } \\
\text { Alpha }\end{array}$ & $\begin{array}{l}\text { Composite } \\
\text { Reliability }\end{array}$ & $\begin{array}{l}\text { Average Variance } \\
\text { Extracted (AVE) }\end{array}$ \\
\hline \multirow[t]{3}{*}{ Collaboration and Interaction } & CI 1 & $0.751 * * *$ & 0.816 & 0.892 & 0.734 \\
\hline & $\mathrm{CI} 2$ & $0.834 * * *$ & & & \\
\hline & CI3 & $0.883^{* * * *}$ & & & \\
\hline \multirow[t]{4}{*}{ Creativity } & CRT1 & $0.611^{* * *}$ & 0.913 & 0.939 & 0.794 \\
\hline & $\mathrm{CRT} 2$ & $0.851 * * *$ & & & \\
\hline & CRT3 & $0.802^{* * * *}$ & & & \\
\hline & CRT4 & $0.729^{* * *}$ & & & \\
\hline \multirow[t]{4}{*}{ Knowledge Sharing } & KS1 & $0.646^{* * * *}$ & 0.934 & 0.953 & 0.835 \\
\hline & $\mathrm{KS} 2$ & $0.783^{* * *} *$ & & & \\
\hline & KS3 & $0.818^{* * * *}$ & & & \\
\hline & $\mathrm{KS} 4$ & $0.751 * * *$ & & & \\
\hline \multirow[t]{3}{*}{ Learning Practices } & $\mathrm{LP}_{1}$ & $0.893^{* * * *}$ & 0.883 & 0.928 & 0.81 \\
\hline & $\mathrm{LP}_{2}$ & $0.918^{* * * *}$ & & & \\
\hline & $\mathrm{LP} 3$ & $0.855^{* * * *}$ & & & \\
\hline \multirow[t]{3}{*}{ Teaching Practices } & $\mathrm{TP} 1$ & $0.893 * * *$ & 0.895 & 0.934 & 0.826 \\
\hline & $\mathrm{TP} 2$ & $0.918^{* * * *}$ & & & \\
\hline & TP3 & $0.855^{* * * *}$ & & & \\
\hline \multirow[t]{5}{*}{ Use of SNS } & US1 & $0.783^{* * * *}$ & 0.871 & 0.905 & 0.657 \\
\hline & $\mathrm{US} 2$ & $0.819^{* * *}$ & & & \\
\hline & US3 & $0.772^{* * * *}$ & & & \\
\hline & US4 & O.836*** & & & \\
\hline & US5 & $0.840^{* * * *}$ & & & \\
\hline
\end{tabular}

After determining the reliability and convergent validity, it is also necessary to determine the distinctiveness of the variables (Ahram, Karwowski, \& Taiar, 2018). In this manner, the HTMT ratio has been used by the researcher for the purpose of recognising the distinctiveness among the variables in which the maximum value which is acceptable is 0.85 (Kergroach, 2017). Therefore, the results presented in Table 2 shows that none of the variable is exceeding the threshold of HTMT ratio and can be allowed for path analysis.

Table-2. Discriminant validity using HTMT Ratio.

\begin{tabular}{|c|c|c|c|c|c|}
\hline & $\begin{array}{c}\text { Collaboration } \\
\text { and Interaction }\end{array}$ & Creativity & $\begin{array}{c}\text { Knowledge } \\
\text { Sharing }\end{array}$ & $\begin{array}{l}\text { Learning } \\
\text { Practices }\end{array}$ & $\begin{array}{l}\text { Teaching } \\
\text { Practices }\end{array}$ \\
\hline \multicolumn{6}{|c|}{ Collaboration and Interaction } \\
\hline Creativity & 0.464 & & & & \\
\hline Knowledge Sharing & 0.391 & 0.745 & & & \\
\hline Learning Practices & 0.525 & 0.584 & 0.536 & & \\
\hline Teaching Practices & 0.321 & 0.572 & 0.505 & 0.574 & \\
\hline Use of SNS & 0.490 & 0.706 & 0.682 & 0.502 & 0.490 \\
\hline
\end{tabular}

\subsection{Path Assessment}

After the assessment of the measurement model which provided the assistance in terms of determining the validity and reliability of the factors involves in latent constructs, the significance of hypothesised paths in the SEM model are tested by the researcher. In this manner, the significance and the effect has been tested with the assistance of bootstrapping model while the results have been reflected in Figure 3 and Table 3. It has been argued in the study of Hair Jr et al. (2016) that bootstrapping is the process of resampling and subsampling for the purpose of determining the significance. In this manner, the results determined from Table 3 suggests that there is a significant and positive impact of collaboration and interaction on the learning practices $(B=0.257 ; p$-value $=$ $0.000<0.01)$. This depicts that the increase in collaboration and interaction will result in the more effective learning practices. 


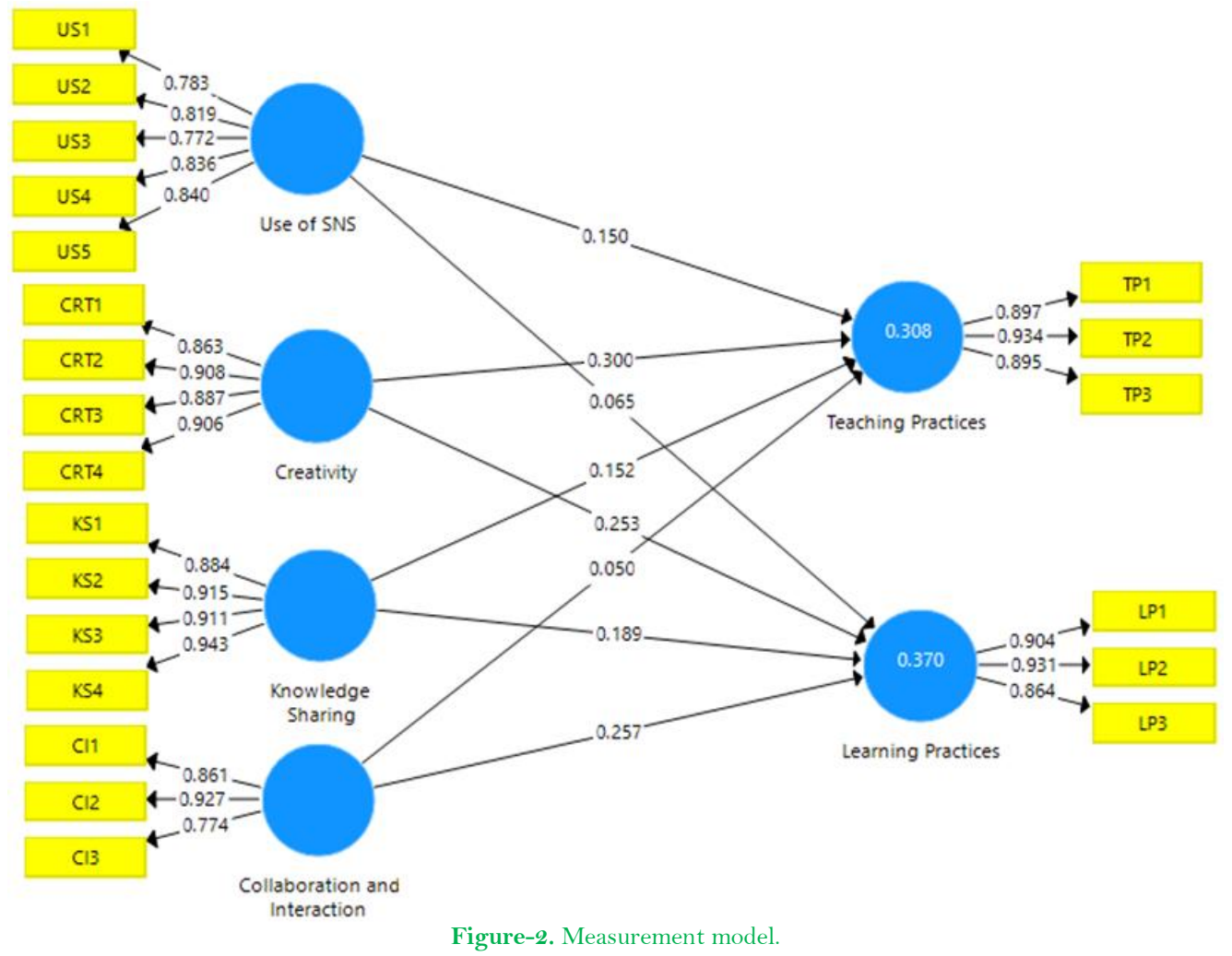

On the other hand, the positive and significant impact of creativity on learning practices has also been determined as $(B=0.253 ; \mathrm{p}$-value $=0.002<0.01)$. Therefore, the increase in creativity will result in the increase of learning practices. Similarly, the impact of creativity on the teaching practices was also determined to be positive and significant as $(B=0.301 ; p$-value $=0.000<0.01)$. In this manner, the increase in creativity will result in the increase of teaching practices. Moreover, the effect of knowledge sharing on the learning practices was also found to be positive and significant as $(B=0.189 ; \mathrm{p}$-value $=0.014<0.05)$. This depicts that the increase in knowledge sharing will cause an increase in learning practices. Likely, the effect of knowledge sharing on the teaching practices was also positive and significant as $(B=0.151 ; \mathrm{p}$-value $=0.089<0.1)$. This shows that that the increase in knowledge sharing will cause an increase in teaching practices. Lastly, the use of SNS also had a significant and positive impact on the teaching practices as $(B=0.149 ; \mathrm{p}$-value $=0.067<0.01)$. It portrays that the use of SNS will have positive effect on the teaching practices. Furthermore, the results have been presented in Figure 3 and Table 3 following the application of bootstrapping along the p-values.

\subsection{Quality Criterion of the Model and Predictive Relevance}

After the assessment of the measurement model along with the assessment of path analysis model, it is necessary to evaluate the predictive relevance and quality of the model. The study of Eckles, Hoyt, and Miller (2014) stated that both the R-squared and adjusted R-squared helps in terms of evaluating the quality of model. Therefore, the results which have been presented in Table 4 along with the variance in all the factors including collaboration and interaction, knowledge sharing, creativity and use of SNS is explaining $37 \%$ of the variance in the learning practices. However, this value has been computed as $36.1 \%$ after making the adjustments. 
Table-3. Path analysis.

\begin{tabular}{lcc}
\hline & $\begin{array}{c}\text { Path } \\
\text { Coefficient }\end{array}$ & $\begin{array}{c}\text { T Statistics } \\
(|\mathbf{S T D E V}|)\end{array}$ \\
\hline Values
\end{tabular}

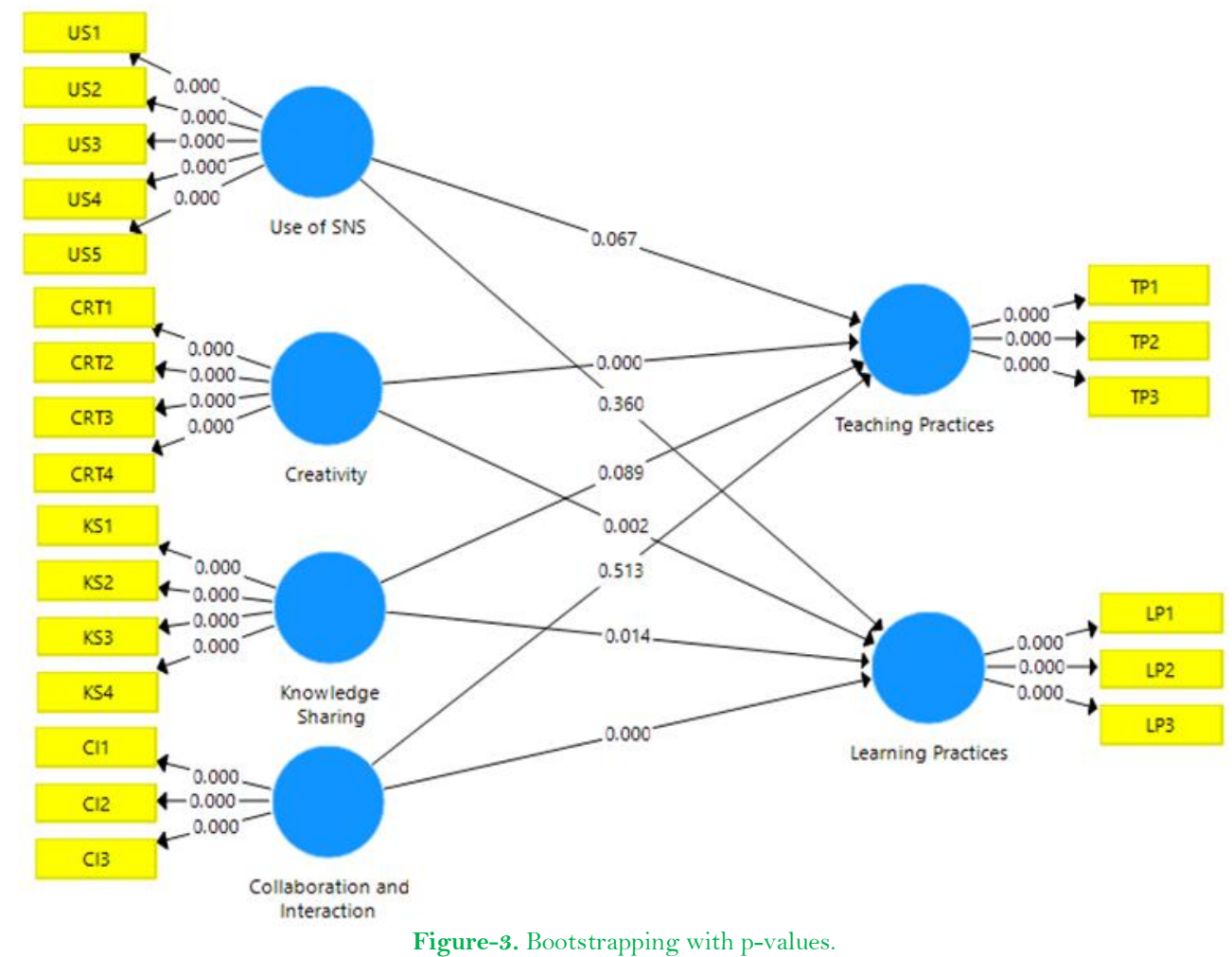

On the other hand, the model also identified that variance in all the factors including collaboration and interaction, knowledge sharing, creativity and use of SNS is explaining $30.8 \%$ of the variance in teaching practices. In contrast to this, the variance has been obtained as $29.8 \%$ after the adjustment. Moreover, it has been argued in the study of Wong (2011) that it is essential for the value of $Q$ to be above $O$ for the intent to deem the model while having the predictive relevance. Therefore, it can be determined with the help of Table 4 and Figure 4 that Qsquare for learning practices is 0.268 while the $Q$-square for teaching practices is obtained as 0.222 . This depicts that the $Q$-square for both the constructs are well above 0 .

Table-4. Quality assessment of the model.

\begin{tabular}{lccc}
\hline & R Square & R Square Adjusted & Q Square \\
\hline Learning Practices & $37 \%$ & $36.1 \%$ & 0.268 \\
Teaching Practices & $30.8 \%$ & $29.8 \%$ & 0.222 \\
\hline
\end{tabular}




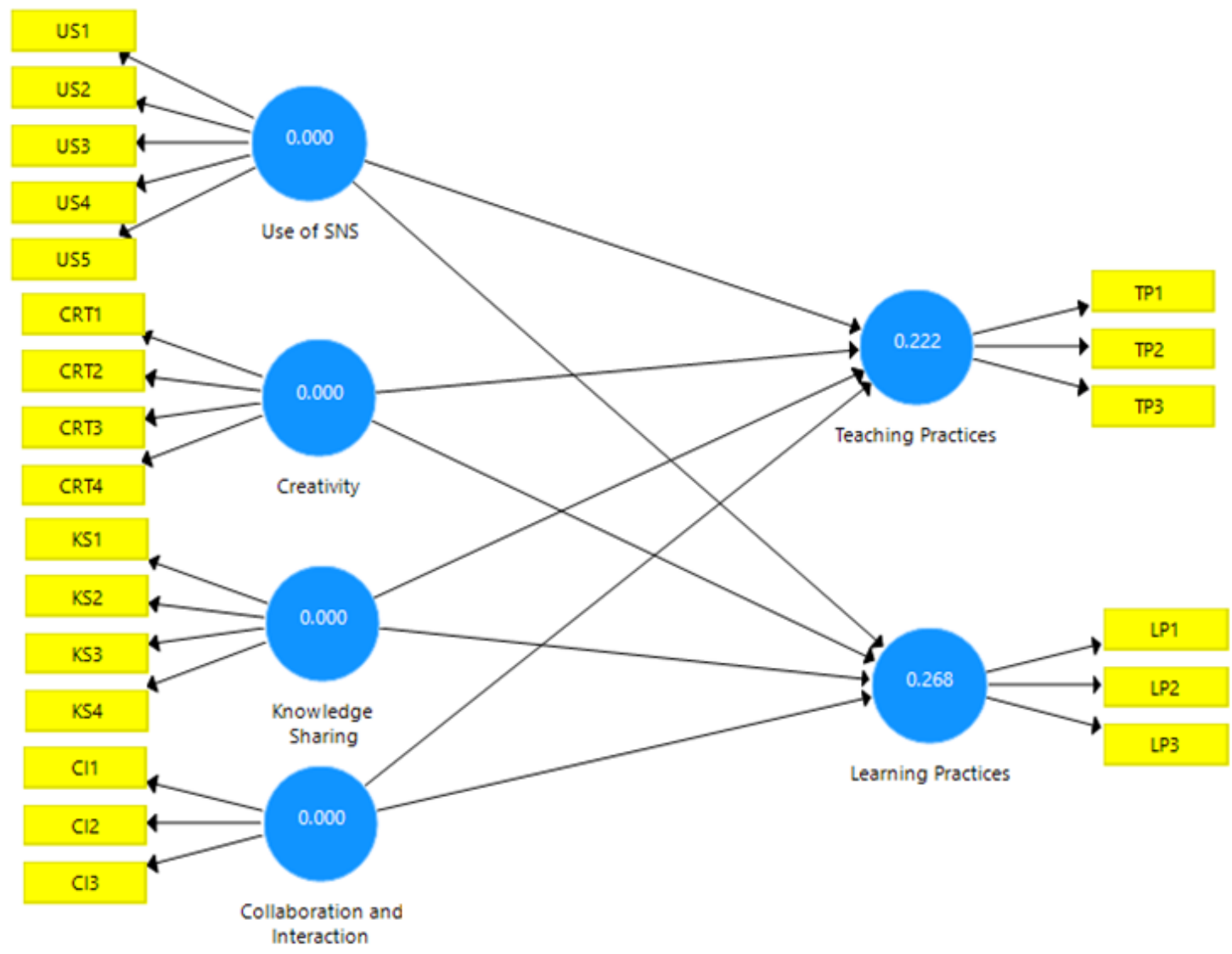

Figure-4. Blindfolding.

\subsection{Summary of Hypotheses}

The hypothesis which have been developed in the prior section of the study have been summarised in this section of the study. The results of these hypothesis have been based on the analysis which has been carried out in the above section. This depicts that all the hypothesis in this study have been accepted except the two of them. This is due to the reason that the use of social networking sites had insignificant influence over learning practices. Moreover, the collaboration and interaction also had insignificant influence over teaching practices. These hypotheses have been reflected in Table 5 which has been presented below:

Table-5. Table of hypotheses assessment summary.

\begin{tabular}{|c|c|}
\hline Propositions & Decision \\
\hline H1: Use of social networking sites have significant influence over teaching practices. & Accepted \\
\hline H2: Use of social networking sites have significant influence over learning practices. & Rejected \\
\hline H3: Creativity through social media have significant influence over teaching practices. & Accepted \\
\hline H4: Creativity through social media have significant influence over learning practices. & Accepted \\
\hline $\begin{array}{l}\text { H5: Knowledge sharing through social media have significant influence over teaching } \\
\text { practices. }\end{array}$ & Accepted \\
\hline $\begin{array}{l}\text { H6: Knowledge sharing through social media have significant influence over learning } \\
\text { practices. }\end{array}$ & \\
\hline H7: Collaboration and Interaction on SNS have significant influence over teaching practices. & Rejected \\
\hline H8: Collaboration and Interaction on SNS have significant influence o & Accepted \\
\hline
\end{tabular}

\section{DISCUSSION}

This section of the study carried out the discussion which is based on the analysis carried out in the prior section of this study. In this manner, the analysis determined that use of social networking sites have significant influence over teaching practices. This has also been supported in the study of Hamat et al. (2012) that the notion of 
social media cooperative learning with the help of SNS like applications for the conference, Facebook, YouTube, Email or other types of websites let the students in to discuss and communicate well with the teachers and other students. Moreover, the use of social networking sites had insignificant influence over learning practices. The study of Hamat et al. (2012) oppose the findings and stated that students find it easy to learn through social networking sites as they spend most of the time while socialising.

In addition to this, it has also been determined that creativity through social media have significant influence over teaching practices. This has also been supported in the study of McWilliam and Dawson (2007) that the creativity of students in academics has been associated with the creative undertakings in the educational structure which depends typically on the concerted activities of a teacher. Additionally, the creativity through social media also had significant influence over learning practices. This also align with the results of Khan et al. (2017) that critical thinking ability of the student is developed by social networking along with the augmentation and confidence. Moreover, the results identified that Knowledge sharing through social media have significant influence over teaching practices. The study of Khan et al. (2017) also confirms that the use of SNS helps teachers in terms of dealing with everyday issues while encouraging collaboration which is because that the use of SNS allows the teachers to share relevant information with the students.

In addition to this, the analysis identified that Knowledge sharing through social media have significant influence over learning practices. This also aligns with the findings of Johnson (2016) that sharing knowledge over the internet helps the student in terms of learning the different aspects with the discussion. However, the analysis identified the insignificant effect of Collaboration and Interaction on teaching practices. This is opposed from the study of Khan et al. (2017) which argued that collaborating and increasing the interaction of students helps in terms of effective teaching. Lastly, the effect of Collaboration and Interaction on learning practices was identified to be significant.

\section{CONCLUSION AND LIMITATIONS}

This study has been conducted to determine the impact of social media on the teaching and learning practices. In this manner, the problem generates with the lack of use of social networking sites in learning and teaching practices. This may be due to the lack of awareness among teachers and students. This generates the need for both of them to realise the significance of social networking sites. In this regard, the researcher has adopted the quantitative design of the study in which the data has been gathered from 280 respondents using the primary method of data collection through survey questionnaire. For the analysis, Smart PLS has been used to assess the importance of social media on teaching and learning practices. Moreover, SEM (structural equation modelling), CFA (confirmatory factor analysis) and path analysis have been used.

The analysis identified that Use of social networking sites have significant influence over teaching practices however, it had insignificant influence over the learning practices. On the other hand, Creativity through social media have significant influence over both the teaching practices and learning practices. Moreover, the Knowledge sharing through social media have significant influence over teaching and learning practices. While the Collaboration and Interaction on SNS have insignificant influence over teaching practices however, it had significant influence over the learning practices. With respect to the limitations of this study, it can be determined that the study has focused on determining the impact of social media on the teaching and learning practices. In this manner, the results of this study are restricted to educational practices. Therefore, it is recommended for the future researchers to identify the effect of social networking sites on other aspects like job learning, skills learning and knowledge sharing. 


\section{REFERENCES}

Abbas, J., Aman, J., Nurunnabi, M., \& Bano, S. (2019). The impact of social media on learning behavior for sustainable education: evidence of students from selected universities in Pakistan. Sustainability, 11(6), 1-23.

Ahram, T., Karwowski, W., \& Taiar, R. (2018). Human Systems Engineering and Design. Paper presented at the In Conference proceedings IHSED.

Avkiran, N., \& Ringle, C. (2018). Partial least squares structural equation modeling. Handbook of Market Research, 267 , 1-29. Available at: https://doi.org/10.1007/978-3-319-71691-6_1.

Chu, S.-C., \& Kim, Y. (2011). Determinants of consumer engagement in electronic word-of-mouth (eWOM) in social networking sites. International journal of Advertising, 30(1), 47-75. Available at: https://doi.org/10.2501/ija-30-1-047-075.

Devi, K., Gouthami, E., \& Lakshmi, V. (2019). Role of social media in teaching-learning process. Retrieved from Journal of Emerging Technologies and Innovative Research (JETIR), 6(2), 96-103.

Eckles, D. L., Hoyt, R. E., \& Miller, S. M. (2014). Reprint of: The impact of enterprise risk management on the marginal cost of reducing risk: Evidence from the insurance industry. Journal of Banking \& Finance, 49, 409-423. Available at: https://doi.org/10.1016/j.jbankfin.2014.10.006.

Eginli, A. T., \& Tas, N. O. (2018). Interpersonal communication in social networking sites: An investigation in the framework of uses and gratification theory. Online Journal of Communication and Media Technologies, 8(2), 81-104.

Hair Jr, J. F., Hult, G. T. M., Ringle, C., \& Sarstedt, M. (2016). A primer on partial least squares structural equation modeling (PLSSEM). Sage Publications.

Hamat, A., Embi, M. A., \& Hassan, H. A. (2012). The use of social networking sites among Malaysian university students. International Education Studies, 5(3), 56-66. Available at: https://doi.org/10.5539/ies.v5n3p56.

Hamid, S., Waycott, J., Chang, S., \& Kurnia, S. (2011). Appropriating online social networking (OSN) activities for higher education: Two Malaysian cases. Paper presented at the Changing Demands, Changing Directions. Proceedings ascilite Hobart.

Javaeed, A., Kibria, Z., Khan, Z., \& Ghauri, S. (2020). Impact of social media integration in teaching methods on exam outcomes. Advances in Medical Education and Practice, 11, 53-61. Available at: https://doi.org/10.2147/amep.s209123.

Jefferies, A., \& Cubric, M. (2015). ECEL2015-14th European Conference on e-Learning: ECEl2015. Paper presented at the Academic Conferences and Publishing Limited.

Johnson, C. M. (2016). Rethinking online discourse: Improving learning through discussions in the online classroom. Education and Information Technologies, 21(6), 1483-1507. Available at: https://doi.org/10.1007/s 10639-015-9395-3.

Kalpidou, M., Costin, D., \& Morris, J. (2011). The relationship between Facebook and the well-being of undergraduate college students. Cyber Psychology, Behavior, and Social Networking, 14(4), 183-189. Available at: https://doi.org/10.1089/cyber.2010.0061.

Kergroach, S. (2017). Industry 4.0: New challenges and opportunities for the labour market. Foresight, 11 (4 (eng)), 6-8. Available at: https://doi.org/10.17323/2500-2597.2017.4.6.8.

Khan, M. I., Ahmed, M., \& Amin, A. (2017). The impact of social media on teacher's performance: A case of higher educational institutions of Pakistan. European Online Journal of Natural and Social Sciences, 6(2), 206-220.

McWilliam, E., \& Dawson, S. (2007). Understanding creativity: A survey of 'creative'academic teachers. Canberra, Australia: The Carrick Institute for Learning and Teaching in Higher Education.

Moran, M., Seaman, J., \& Tinti-Kane, H. (2011). Teaching, learning, and sharing: How today's higher education faculty use social media. Babson Survey Research Group.

Roblyer, M. D., McDaniel, M., Webb, M., Herman, J., \& Witty, J. V. (2010). Findings on Facebook in higher education: A comparison of college faculty and student uses and perceptions of social networking sites. The Internet and Higher Education, 13(3), 134-140. Available at: https://doi.org/10.1016/j.iheduc.2010.03.002. 
Urista, M. A., Dong, Q., \& Day, K. D. (2009). Explaining why young adults use MySpace and Facebook through uses and gratifications theory. Human Communication, 12(2), 215-229.

Vinzi, V. E., Chin, W. W., Henseler, J., \& Wang, H. (2010). Handbook of partial least squares (Vol. 201). Germany: Springer. Wang, Q., Chen, W., \& Liang, Y. (2011). The effects of social media on college students. MBA Student Scholarship, 5, 1-12.

Wong, K. K.-K. (2011). Book review: Handbook of partial least squares: Concepts, methods and applications.

Online Science Publishing is not responsible or answerable for any loss, damage or liability, etc. caused in relation to/arising out of the use of the content. Any queries should be directed to the corresponding author of the article. 